\title{
Revelação e Existência Uma abordagem teológica sobre o lugar do símbolo para o conhecimento de Deus no mundo contemporâneo
}

\author{
Orientador: Maria Clara Lucchetti Bingemer \\ Mestrando: Silvana Gomes Venancio Cabral \\ Área de Concentração: Teologia Sistemático-Pastoral \\ Linha de Pesquisa: Religião e Modernidade
}

O propósito desta pesquisa foi refletir sobre a revelação de um Deus transcendente e a sua relação com um ser humano finito. Ao se perguntar sobre essa relação, a pesquisa se norteou pela a ideia de como é possível o conhecimento de Deus, condicionado pela finitude humana, e como esse conhecimento corre o risco de se tornar um conhecimento como outro qualquer. Pois a única maneira de o ser humano conhecer a realidade a sua volta é sempre através da estrutura sujeito-objeto. Porém, Deus não pode ser um objeto entre outros. Sendo assim, a pesquisa propôs a estudar a teologia de Paul Tillich, um teólogo que postula o conceito de símbolo como linguagem da fé, sendo um caminho para que a revelação de Deus seja acolhida, sem tornar Deus objeto de idolatria e fanatismos. Para responder a esses questionamentos, no primeiro momento a pesquisa perpassou os limites da razão humana, através da contribuição de alguns filósofos, fazendo uma relação entre finitude e existência humana. Num segundo momento a pesquisa se estabeleceu sobre a relação entre a revelação de um Deus transcendente e a experiência humana, no cotidiano. A experiência de uma revelação que exige aproximação, que não é algo fora, objetivo, mas existencial. Por último a pesquisa se deteve sobre a fé como uma dimensão inerente ao ser humano, uma fé que se comunica através de símbolos, mediada pela linguagem e que tenta fugir de todos os propósitos fundamentalistas de dominação e imposição.

Palavras-chave: Existência; Revelação; Razão; Símbolo; Linguagem; Fé; Experiência; Fundamentalismo; Paul Tillich. 